\title{
Estimation of Genetic Parameters on Pre-weaning Growth Traits in Hanwoo
}

\author{
J. M. Hwang*, J. G. Choi*, H. C. Kim*, Y. H. Choy*, C. Lee**, B. K. Yang***, J. S. Shin*** \\ and J. B. Kim***
}

National Livestock Research Institute, Institute of Environment*, Life Science, Hallym University**, College of Animal Life Science, Kangwon National University***

\section{한우의 이유전 성장형질에 관한 유전모수 추정}

황정미* . 최재관* . 김형철* . 최연호* . 이채영** . 양부근*** . 신종서*** . 김종복***

축산연구소*, 한림대학교 생명과학연구소**, 강원대학교 동물생명과학대학***

\section{요 약}

본 연구에서는 축산연구소 한우시험장에서 1970년부터 2005년까지 출생한 한우 4,627두의 이유전 성장형 질(생시체중, 이유시 체중, 이유전 일당증체량)에 대한 유전모수를 추정하기 위해 실시하였다. 유전모수 추 정은 두 가지 모형을 이용하여 실시되었는데, 모형 1 에서 추정한 개체효과의 유전력은 0.34 , 이유시 체중에 서 0.26 , 이유전 일당증체량에서 0.20 이었다. 모형 2 를 이용하여 추정한 개체 유전효과의 유전력과 모체 유 전효과의 유전력은 생시체중에서 0.14 와 0.06 , 이유시 체중에서 0.07 과 0.04 그리고 포유기 일당증체량에서 0.05 와 0.04 이었고, 개체효과와 모체효과간의 유전상관계수는 생시체중에서 0.58 , 이유시 체중에서 0.75 그 리고 포유기 일당증체량에서 0.61 이었다. 모형 1 을 이용하여 추정한 생시체중과 이유시 체중 간, 생시체중 과 포유기 일당증체량 간, 그리고 이유시 체중과 포유기 일당증체량 간의 유전상관은 각각 $0.76,0.62$ 및 0.99 였다. 포유기 일당증체량과 이유시 체중 사이의 유전상관계수가 높게 추정된 결과는 포유기 일당증체 량에 대한 선발을 통해 한우 집단의 이유시 체중을 효과적으로 증대시킬 수 있을 것임을 시사한다.

(Key words : Birth weight, Weaning weight, ADG, Heritability, Genetic correlation)

\section{I . INTRODUCTION}

To improve pre-weaning productivity of cattle, cow-calf producers have been trying to increase weaning weight of their calves through management and genetics (Fiss and Wilton, 1993). Preweaning ability of an animal is determined by inherent genes from its parents and milking production and mothering ability of its dam called maternal effect. Most of the literature reported that the maternal ability of beef cows had been shown to be a critical component for pre-weaning growth of their calves (Freking and Marshall, 1992; Fiss and Wilton, 1993; Mallinckrodt et al., 1993; Brown and Brown, Jr. 2002).

The objective of this study was to estimate genetic relationships between pre-weaning growth traits in Hanwoo.

Corresponding author: Jongbok Kim, College of Animal Life Sciences, Kangwon National University, Chuncheon, 200-701, Korea

Tel : 033-250-8624, E-mail : jbkim@kangwon.ac.kr 


\section{MATERIALS AND METHODS}

A total of 4,627 records on pre-weaning growth traits, birth weight (BW), weaning weight (WW), pre-weaning daily gain (ADG) of Hanwoo's born from 1970 to 2005 were collected from Hanwoo Experiment Station, National Livestock Research Institute. BW of calf was measured within 24h after birth and age at measuring WW ranged from 90 to 150 days of age.

Variance components and heritabilities of BW, WW and ADG were estimated with two models.

Model $1: \mathrm{y}=\mathrm{X} \beta+\mathrm{Z}_{\mathrm{d}} \mathrm{u}_{\mathrm{d}}+\mathrm{e}$

Model $2: \mathrm{y}=\mathrm{X} \beta+\mathrm{Z}_{\mathrm{d}} \mathrm{u}_{\mathrm{d}}+\mathrm{Z}_{\mathrm{m}} \mathrm{u}_{\mathrm{m}}+\mathrm{Z}_{\mathrm{pe}} \mathrm{u}_{\mathrm{pe}}+\mathrm{e}$

Where, $y$ is a $N \times 1$ vector of observations, $\beta$ is a vector of fixed effects-contemporary group (birth year-season-sex), age of dam and weaning age of calf, $u_{d}$ is a vector of additive genetic effect, $u_{m}$ is a vector of maternal genetic effect, $\mathrm{u}_{\mathrm{pe}}$ is a vector of permanent environmental effect. And $\mathrm{X}, \mathrm{Z}_{\mathrm{d}}, \mathrm{Z}_{\mathrm{m}}, \mathrm{Z}_{\mathrm{pe}}$ are incidence matrices linking fixed effects and random effects with observations.

The (co)variance structures of random effects for Model 1 was

$\operatorname{Var}\left[\begin{array}{c}u_{d} \\ e\end{array}\right]=\left[\begin{array}{cc}A \sigma_{d}^{2} & 0 \\ 0 & I \sigma_{e}^{2}\end{array}\right]$

and that for Model 2 was

$\operatorname{Var}\left[\begin{array}{c}u_{d} \\ u_{m} \\ u_{p e} \\ e\end{array}\right]=\left[\begin{array}{cccc}A \sigma_{d}^{e} & A \sigma_{d m} & 0 & 0 \\ A \sigma_{d m} & A \sigma_{m}^{2} & 0 & 0 \\ 0 & 0 & I \sigma_{p e}^{2} & 0 \\ 0 & 0 & 0 & I \sigma_{e}^{2}\end{array}\right]$

Where $\sigma_{d}{ }^{2}$ is direct genetic variance, $\sigma_{m}{ }^{2}$ is maternal genetic variance, $\sigma_{d m}$ is covariance between direct and maternal genetic effect, $\sigma_{p e}{ }^{2}$ is permanent environmental variance, and $\sigma_{e}{ }^{2}$ is random residual variance. $A$ is a numerator relationship matrix among animals in pedigree file, and the $I$ matrices are identity matrices.

Table 1. Distribution of records by birth year, birth season and sex

\begin{tabular}{crrrrrrr}
\hline Year & N & Year & N & Season & N & Sex & N \\
\hline \hline $1970 ~ 1980$ & 669 & 1994 & 174 & Winter & 241 & Female & 2,405 \\
1981 & 96 & 1995 & 194 & Spring & 2,326 & Male & 2,222 \\
1982 & 139 & 1996 & 212 & Summer & 1,316 & & \\
1983 & 103 & 1997 & 188 & Fall & 580 & & \\
1984 & 115 & 1998 & 228 & Unknown & 164 & & \\
1985 & 73 & 1999 & 183 & & & & \\
1986 & 151 & 2000 & 206 & & & & \\
1987 & 137 & 2001 & 214 & & & & \\
1988 & 128 & 2002 & 167 & & & & \\
1989 & 174 & 2003 & 137 & & & & \\
1990 & 117 & 2004 & 147 & & & & \\
1991 & 124 & 2005 & 86 & & & & \\
1992 & 146 & Unknown & 164 & & & & \\
1993 & 155 & & & & & & \\
\hline Total & & & 4,627 & & & & \\
\hline
\end{tabular}

Winter : Dec. Feb., Spring : Mar. May, Summer: Jun Aug., Fall : Sep. Nov. 
MTDFREML program (Boldman et al, 1995) was used for genetic parameter estimation. Global maximum likelihood estimates were iteratively estimated using estimates from previous run as priors with each run to go until the variation was less then $10^{-11}$. Two trait analyses using model 1 were performed to obtain covariance among traits.

\section{RESULT AND DISCUSSION}

Table 2 reports summary statistics for BW, WW and ADG in this sample.

The averages of BW, WW and ADG were $24.39 \mathrm{~kg}, 91.77 \mathrm{~kg}$ and $0.547 \mathrm{~kg}$, respectively.

Additive direct genetic variances of preweaning traits estimated from model 1 are shown in Table 3. Heritability estimates for BW, WW and ADG from model 1 were 0.34, 0.26 and 0.20 , respectively. Heritability estimates for BW, WW and ADG in this study were within the range of literature values. Ferreira et al. (1999) estimated direct heritabilities of direct BW and direct WW as 0.28 and 0.16 in Hereford. Aziz et al. (2005) reported that heritabilities of BW and 120d weight in Japanese Black cattle were 0.38 and 0.65. Koots et al. (1994) summarized published genetic parameter estimates and reported that weighted average estimates of heritability for BW, WW and ADG were 0.31, 0.24 and 0.29, respectively.

Additive genetic, maternal genetic and permanent environmental variances of pre-weaning traits estimated from model 2 are shown in Table 4. Maternal heritability estimates ranged from 0.04 to 0.06 . Direct heritability estimates ranged from 0.05 to 0.14 for BW, WW and ADG. Genetic correlations between direct and maternal genetic effects were estimated positive; 0.58, 0.75 and 0.61 for $\mathrm{BW}, \mathrm{WW}$ and $\mathrm{ADG}$, respectively. It is suggested that maternal effect for WW and ADG may positively interact with direct genetic effect during selection process.

Meyer (1992) reported that genetic correlations between direct and maternal genetic effect for BW were 0.038 in Hereford and 0.285 in Angus

Table 2. Simple statistics of pre-weaning traits, age of dam and age at weaning

\begin{tabular}{cccccc}
\hline Trait & $\mathrm{n}$ & mean & std & Max & $\min$ \\
\hline \hline BW & 4,191 & 24.39 & 3.76 & 40 & 10 \\
WW & 3,136 & 91.77 & 20.31 & 26 & 179 \\
ADG & 3,133 & 0.547 & 0.153 & 1.287 & 0.045 \\
AOD & 4,346 & $1,960.5$ & $1,015.2$ & 6,881 & 461 \\
Wage & 3,136 & 122.9 & 11.2 & 150 & 90 \\
\hline
\end{tabular}

BW : Birth weight $(\mathrm{kg})$, WW : Weaning weight $(\mathrm{kg})$, ADG : Preweaning daily gain $(\mathrm{kg})$, AOD : Age of dam (day), Wage : Weaning age of calf (day).

Table 3. Additive direct genetic variance of pre-weaning traits

\begin{tabular}{ccccc}
\hline Trait & $\sigma_{\mathrm{d}}{ }^{2}$ & $\sigma_{\mathrm{e}}{ }^{2}$ & $\sigma_{\mathrm{t}}{ }^{2}$ & $\mathrm{~h}^{2}$ \\
\hline \hline BW & 3.73 & 7.33 & 11.06 & 0.34 \\
WW & 68.65 & 191.01 & 259.66 & 0.26 \\
ADG & 0.003 & 0.012 & 0.016 & 0.20 \\
\hline
\end{tabular}

${\sigma_{\mathrm{d}}}^{2}$ : Direct genetic variance, $\sigma_{\mathrm{e}}{ }^{2}$ : Environmental variance, $\sigma_{\mathrm{t}}^{2}=\sigma_{\mathrm{d}}{ }^{2}+\sigma_{\mathrm{e}}{ }^{2}, \mathrm{~h}^{2}$ : Direct heritability. 
Table 4. Additive direct genetic, maternal genetic and permanent environmental variance of pre-weaning traits

\begin{tabular}{crrrrrrrrr}
\hline Trait & \multicolumn{1}{c}{$\sigma_{\mathrm{d}}{ }^{2}$} & \multicolumn{1}{c}{$\sigma_{\mathrm{m}}{ }^{2}$} & \multicolumn{1}{c}{$\sigma_{\mathrm{dm}}$} & \multicolumn{1}{c}{$\sigma_{\mathrm{pe}}{ }^{2}$} & $\sigma_{\mathrm{e}}{ }^{2}$ & $\sigma_{\mathrm{p}}{ }^{2}$ & $\mathrm{~h}_{\mathrm{d}}{ }^{2}$ & $\mathrm{~h}_{\mathrm{m}}{ }^{2}$ & $\mathrm{r}_{\mathrm{dm}}$ \\
\hline \hline BW & 1.55 & 0.62 & 0.57 & 0.10 & 7.99 & 10.82 & 0.14 & 0.06 & 0.58 \\
WW & 17.82 & 10.30 & 10.15 & 14.71 & 190.03 & 243.01 & 0.07 & 0.04 & 0.75 \\
ADG & 0.001 & 0.001 & 0.000 & 0.001 & 0.012 & 0.015 & 0.05 & 0.04 & 0.61 \\
\hline
\end{tabular}

$\sigma_{\mathrm{d}}^{2}$ : Direct genetic variance, $\sigma_{\mathrm{m}}{ }^{2}:$ Maternal genetic variance, $\sigma_{\mathrm{dm}}$ : Direct maternal genetic covariance, $\sigma_{\mathrm{pe}}{ }^{2}$ : Permanent environmental variance, $\sigma_{\mathrm{e}}{ }^{2}$ : Environmental variance, $\sigma_{\mathrm{p}}{ }^{2}$ : Phenotypic variance, $\mathrm{h}_{\mathrm{d}}{ }^{2}$ : Direct heritability, $\mathrm{h}_{\mathrm{m}}^{2}$ : Maternal heritability, $\mathrm{r}_{\mathrm{dm}}$ : Correlation between direct and maternal effect.

and those for WW were -0.587 in Hereford, 0.223 in Angus and -0.783 in Zebu Cross. Ferreira et al. (1996) reported that genetic correlation between direct and maternal was -0.33 for WW. Koots et al. (1994) reported that weighted genetic correlation between direct and genetic effects for WW was -0.20 .

Genetic (co)variance components and genetic (phenotypic) correlation coefficients between preweaning traits from bi-variable analyses are shown in Table 5. Genetic (phenotypic) correlation coefficients between BW and WW, between BW and ADG, and between WW and ADG were 0.76 (0.34), 0.62 (0.17) and 0.99 (0.97), respectively.

Heritability estimates from single trait analyses and from two trait analyses came out to be the same. ADG and WW can be thought of as the same traits because genetic correlation between these was close to unity. Genetic correlation coefficients were higher than phenotypic correlation coefficients between BW and WW and between BW and ADG in the study. Our results accord with the results of Aziz et al. (2005) where direct genetic correlation coefficients among birth

Table 5. Estimates of (co)variance components among pre-weaning traits

\begin{tabular}{|c|c|c|c|c|c|c|c|c|c|}
\hline Traits & $\sigma_{\mathrm{d} 1}^{2}$ & $\sigma_{\mathrm{d} 2}{ }^{2}$ & $\sigma_{\mathrm{d} 12}$ & $\sigma_{\mathrm{e} 1}^{2}$ & $\sigma_{\mathrm{e} 2}^{2}$ & $\sigma_{\mathrm{e} 12}$ & $\sigma_{\mathrm{p} 1}^{2}$ & $\sigma_{\mathrm{p} 2}{ }^{2}$ & $\sigma_{\mathrm{p} 12}$ \\
\hline $\mathrm{BW} \times \mathrm{WW}$ & 3.76 & 61.72 & 11.52 & 7.33 & 187.40 & 7.69 & 11.08 & 249.12 & 19.21 \\
\hline $\mathrm{BW} \times \mathrm{ADG}$ & 3.745 & 0.003 & 0.064 & 7.331 & 0.012 & 0.004 & 11.076 & 0.015 & 0.068 \\
\hline $\mathrm{WW} \times \mathrm{ADG}$ & 65.656 & 0.003 & 0.439 & 184.363 & 0.012 & 1.452 & 250.019 & 0.015 & 1.892 \\
\hline & \multicolumn{2}{|c|}{$\mathrm{h}_{\mathrm{d} 1}^{2}$} & \multicolumn{3}{|c|}{$\mathrm{h}_{\mathrm{d} 2}^{2}$} & $r_{\mathrm{d} 12}$ & & \multicolumn{2}{|l|}{$\mathrm{r}_{\mathrm{p} 12}$} \\
\hline $\mathrm{BW} \times \mathrm{WW}$ & \multicolumn{2}{|c|}{0.34} & \multicolumn{2}{|r|}{0.25} & \multicolumn{3}{|c|}{0.76} & \multicolumn{2}{|l|}{0.37} \\
\hline $\mathrm{BW} \times \mathrm{ADG}$ & \multicolumn{2}{|c|}{0.34} & \multicolumn{2}{|r|}{0.19} & \multicolumn{3}{|c|}{0.62} & \multicolumn{2}{|l|}{0.17} \\
\hline $\mathrm{WW} \times \mathrm{ADG}$ & \multicolumn{2}{|c|}{0.26} & \multicolumn{2}{|r|}{0.20} & \multicolumn{2}{|r|}{0.99} & & \multicolumn{2}{|l|}{0.97} \\
\hline
\end{tabular}

BW : Birth weight $(\mathrm{kg})$, WW : weaning weight $(\mathrm{kg})$, ADG : Pre-weaning daily gain $(\mathrm{kg})$

$\sigma_{\mathrm{d} 1 \text { (or 2) }}{ }^{2}$ : Direct genetic variance of traits 1 (or 2), $\sigma_{\mathrm{d} 12}$ : Genetic covariance between trait 1 and trait 2, $\sigma_{\mathrm{e} 1 \text { ( or } 2)^{2}}$ : Environmental variance of trait 1 (or 2), $\sigma_{\mathrm{e} 12}$ : Environmental covariance between trait 1 and trait 2, $\sigma_{\mathrm{p} 1 \text { (or 2) }}{ }^{2}$ : Phenotypic variance of trait 1 (or 2), $\sigma_{\mathrm{p} 12}$ : Phenotypic covariance between trait 1 and trait $2, \mathrm{~h}_{\mathrm{d} 1 \text { (or 2) }}{ }^{2}$ : Direct heritability of trait 1 (or 2), $\mathrm{r}_{\mathrm{d} 12}$ : Genetic correlation between two traits, $\mathrm{r}_{\mathrm{p} 12}$ : Phenotypic correlation between two traits. 
weight, weight at 90 days of age, weight at 120 days of age were higher than phenotypic correlation coefficients. Gregory et al. $(1995$, b) reported genetic and phenotypic correlation coefficient between birth weight and weight at 200 days of age similar to our results in female mixed breed population. However, they (Gregory et al. 1995, a) showed lower genetic correlation coefficients than phenotypic correlation coefficients between birth weight and pre-weaning average daily gain, and between birth weight and weight at 200 days of age in intact male population of beef cattle. This was due to negative genetic correlation between birth weight and 200 days weight. In the paper by Koots et al. (1994), genetic (phenotypic) correlation coefficients were $0.50(0.46)$ between $\mathrm{BW}$ and $\mathrm{WW}, 0.26$ (0.18) between BW and ADG and $0.98(0.98)$ between WW and ADG. This supports close correlation between ADG and WW found in our study. This means that WW is more of a function of $\mathrm{ADG}$ than of sole genetic potential embedded in BW. Therefore, to increase WW, we need to select breeding stock with superior genetic potential of pre-weaning $\mathrm{ADG}$.

\section{ABSTRACT}

A total of 4,627 records on pre-weaning growth traits, birth weight (BW), weaning weight (WW) and pre-weaning daily gain (ADG) of Hanwoo's born form 1970 to 2005 were collected from Hanwoo Experiment Station, National Livestock Research Institute. Variance components and heritabilities of BW, WW and ADG were estimated with two models; Model 1 included only direct genetic effect while Mode1 2 included direct genetic, maternal genetic and permanent environmental effects. Direct heritability estimates of BW, WW and ADG estimated by model 1 were $0.34,0.26$ and 0.20 , respectively. In model 2 , direct heritability and maternal genetic heritability estimates were 0.14 and 0.06 for BW, 0.07 and 0.04 for WW and 0.05 and 0.04 for ADG. Estimates of genetic correlation between direct and maternal effect for BW, WW and ADG were 0.58, 0.75 and 0.61, respectively. Genetic correlation coefficients between $\mathrm{BW}$ and WW, between BW and ADG, and between WW and ADG were 0.76, 0.62 and 0.99 , respectively.

(Key words : Birth weight, Weaning weight, ADG, Heritability, Genetic correlation)

\section{REFERENCES}

1. Aziz, M. A., Nishida, S., Suzuki, K. and Nishida, A. 2005. Estimation of direct and maternal genetic and permanent environmental effects for weights from birth to 356 days of age in a herd of Japanese Black cattle using random regression. J. Anim. Sci. 83:519-530.

2. Boldman, K. G., Kriese, L. A., Van Vleck, L. D., Van Tassell, C. P. and Kachman, S. D. 1995. A manual for use of MTDFREML. A set of programs to obtain estimates of variance and covariances. USDA, ARS.

3. Brown, M. A. and Brown, Jr. A. H. 2002. Relationship of milk yield and quality to preweaning gain of calves from Angus, Brahman and reciprocal-cross cows on different forage systems. J. Anim. Sci. 80:2522-2527.

4. Ferreira, G. B., MacNeil, M. D. and Van Vleck, L. D. 1999. Variance components and breeding values for growth traits from different statistical models. J. Anim. Sci. 77:2641-2650.

5. Fiss, C. F. and Wilton, J. W. 1993. Contribution of breed, cow weight, and milk yield to the preweaning, feedlot, and carcass traits of calves in three beef breeding system. J. Anim. Sci. 71: 2874-2884.

6. Freking, B. A. and Marshall, D. M. 1992. Interrelaionships of heifer milk production and other biological traits with production efficiency to 
weaning. J. Anim. Sci. 70:646-655.

7. Gregory, K. E., Cundiff, L. V. and Koch, R. M. 1995a. Genetic and phenotypic (co)variances for production traits of intact male populations of purebred and composite beef cattle. J. Anim. Sci. 73:2227-2234.

8. Gregory, K. E., Cundiff, L. V. and Koch, R. M. 1995b. Genetic and phenotypic (co)variances for production traits of female populations of purebred and composite beef cattle. J. Anim. Sci. 73: 2235-2242.

9. Koots, K. R., Gibson, J. P., Smith, C. and Wilton, J. W. 1994. Analyses of published genetic parameters estimates for beef production traits: 1 . Heritability. Anim. Breed. Abstr. 62:309-338.
10. Koots, K. R., Gibson, J. P. and Wilton, J. W. 1994. Analyses of published genetic parameters estimates for beef production traits: 1. Phenotypic and genetic correlations. Anim. Breed. Abstr. 62:825-853.

11. Mallinckrodt, C. H., Bourdon, R. M., Golden, B. L., Schalles, R. R. and Odde, K. G. 1993. Relationship of maternal milk expected progeny differences to actual milk yield and calf weanging weight. J. Anim. Sci. 71:335-362.

12. Meyer, K. 1992. Variance component due to direct and maternal effects for growth traits of Australian beef cattle. Livestock Prod. Sci. 31: 179-204.

(접수일자 : 2006. 11. 28. / 채택일자 : 2007. 3. 19.) 